\title{
1 Antibody Response to CoronaVac Vaccine in Indonesian COVID-19 Survivor
}

2 Author: Rahmat Azhari Kemal, ${ }^{1}$ Dita Kartika Sari, ${ }^{2}$ Ariza Julia Paulina ${ }^{3}$

3 Corresponding author: Rahmat Azhari Kemal (rahmat.azharikemal@lecturer.unri.ac.id)

4 Affiliations:

$5{ }^{1}$ Department of Medical Biology, Faculty of Medicine, Universitas Riau, Pekanbaru, Indonesia;

6 and Biomolecular Laboratory, Arifin Achmad General Hospital of Riau Province, Pekanbaru,

7 Indonesia

$8 \quad{ }^{2}$ Department of Anatomy, Faculty of Medicine, Universitas Riau, Pekanbaru, Indonesia

$9{ }^{3}$ Department of Clinical Pathology, Faculty of Medicine, Universitas Riau, Pekanbaru, Indonesia

10 Address for correspondence: Rahmat A. Kemal, Department of Medical Biology, Faculty of

11 Medicine, Universitas Riau, Jl. Diponegoro no. 1, Pekanbaru, Riau, Indonesia, 28133; email:

12 rahmat.azharikemal@lecturer.unri.ac.id; phone/fax: +62761 83926

13 Article Summary Line: Seropositive COVID-19 survivors had significantly higher antibody

14 response after first dose of CoronaVac vaccine compared to non-survivors and seronegative

15 survivors after second dose of vaccine. 
medRxiv preprint doi: https://doi.org/10.1101/2021.05.28.21254613; this version posted May 29, 2021. The copyright holder for this preprint (which was not certified by peer review) is the author/funder, who has granted medRxiv a license to display the preprint in perpetuity.

It is made available under a CC-BY-NC 4.0 International license .

\section{ABSTRACT}

Several studies have shown that individuals with previous history of SARS-CoV-2 infection had boosted antibody response after single dose of mRNA or adenovirus-vectored vaccines. We wondered whether single dose CoronaVac, a whole-inactivated vaccine, could be considered for COVID-19 survivors in Indonesia. We measured IgG anti-RBD titre among 18 survivors and 37 non-survivors. Among survivors, there were 9 survivors with positive antibody titre (seropositive) before vaccination and 9 seronegative survivors. All respondents received two doses of CoronaVac vaccine at 14-days interval. We found no significant antibody titre difference between non-survivor at 14 or 28 days after second dose as well as seronegative survivor at at 14 days after second dose. Seropositive survivors were rapidly boosted after first dose with higher antibody titer than non-survivors and seronegative survivors after second dose. However, antibody titer did not differ between first and second dose among seropositive survivors. Seropositive COVID-19 survivors could receive single dose of CoronaVac vaccine which could potentially ease the vaccine supply constrain. A long-term follow-up must be conducted to observe difference in antibody response and persistence. vaccines in COVID-19 survivor. All studies shown that individuals with previous history of SARS-CoV-2 infection mounted significantly higher post-vaccination antibody compared to naïve individuals. ${ }^{1-4}$ Indonesia has launched its COVID-19 vaccination programme since

37 January $13^{\text {th }} 2021$ utilising whole-inactivated vaccine, CoronaVac (Sinovac, China). Initially, 
medRxiv preprint doi: https://doi.org/10.1101/2021.05.28.21254613; this version posted May 29, 2021. The copyright holder for this preprint (which was not certified by peer review) is the author/funder, who has granted medRxiv a license to display the preprint in perpetuity.

It is made available under a CC-BY-NC 4.0 International license.

COVID-19 survivor could be vaccinated at least 3 months after PCR confirmation. Due to constrain in global COVID-19 vaccine supply, we wondered whether single dose wholeinactivated vaccine could be considered for COVID-19 survivors in Indonesia.

We conducted preliminary studies among participants with or without prior PCRconfirmed SARS-CoV-2 infection. There were 18 survivors and 37 non-survivors. All participants had CoronaVac vaccination with 14-days interval as initially assigned for adults 18 59 years old. For IgG anti-RBD measurement, 23 non-survivors were sampled at 14 days after second dose (day 28), 13 non-survivors were sampled at 28 days after second dose (day 42) and one non-survivor was sampled at days 28 and 42. Blood samples from six survivors were taken at days $0,14,28$ of vaccination. One survivor was also sampled at day 42 . Three survivors were only sampled at days 0 and 14 . IgG anti-RBD was measured from serum using Elecsys® (Roche Diagnostics). The study was approved by Ethical Committee of the Faculty of Medicine Universitas Riau (No: B/023/UN19.5.1.1.8/UEPPK/2021)

Demographical data of respondents is presented in Table 1. There was a significant difference on COVID duration between seronegative and seropositive survivors, with seropositive survivors had longer duration. There was no significant difference on distance between post-COVID and vaccination time between both groups.

Table 1. Demographical data of respondents

\begin{tabular}{|l|c|c|c|c|c|}
\hline \multicolumn{1}{|c|}{ Groups } & $\mathbf{n}$ & $\begin{array}{c}\text { Female } \\
\mathbf{n}(\%)\end{array}$ & $\begin{array}{c}\text { Age, years } \\
\text { Median (Min- } \\
\text { Max) }\end{array}$ & $\begin{array}{c}\text { COVID-19 } \\
\text { length, days } \\
\text { Mean } \pm \text { SD }\end{array}$ & $\begin{array}{c}\text { Time post } \\
\text { COVID-19, days } \\
\text { Mean } \pm \text { SD }\end{array}$ \\
\hline Total & 55 & $35(63.7 \%)$ & $25(21-51)$ & N/A & N/A \\
\hline Non-survivor* & & & & & \\
\hline
\end{tabular}


medRxiv preprint doi: https://doi.org/10.1101/2021.05.28.21254613; this version posted May 29, 2021. The copyright holder for this preprint (which was not certified by peer review) is the author/funder, who has granted medRxiv a license to display the preprint in perpetuity.

It is made available under a CC-BY-NC 4.0 International license .

\begin{tabular}{|c|c|c|c|c|c|}
\hline Day 28 & 24 & $18(75 \%)$ & $24.5(21-48)$ & N/A & N/A \\
\hline Day 42 & 14 & $9(64.3 \%)$ & $29.5(22-51)$ & N/A & N/A \\
\hline Survivor & & & & & \\
\hline Seronegative & 9 & $5(55.6 \%)$ & $23(22-43)$ & $3.3 \pm 1.7$ & $166.4 \pm 36.0$ \\
\hline Seropositive & 9 & $4(44.4 \%)$ & $26(22-44)$ & $17.0 \pm 5.6$ & $128.7 \pm 33.9$ \\
\hline D28** & 6 & $4(66.7 \%)$ & $24.5(22-44)$ & $17.8 \pm 4.7$ & $130.5 \pm 25.8$ \\
\hline
\end{tabular}

*One non-survivor was tested at both days 28 and 42.

** Three seropositive respondents were not tested at 14 days after second dose.

In CoronaVac Phase II trial, there were two times for antibody measurement, 14 or 28 days after second dose (D28 or D42 after first dose). ${ }^{5}$ In our study, there were 2 persons, one non-survivor and one seronegative survivor, measured at both times. Both persons showed increased antibody titer at D42 compared to D28, indicating D42 (28 days after second dose) as more representative time for immune response measurement. However, ANOVA and Bonferroni Post-hoc analysis showed no significant difference of IgG anti-RBD titre between non-survivor at days 28 and 42 as well as seronegative survivor at day 28 (Table 1). Using one sample t-test, the titre of each group was also not significantly different with Phase II trial result.

Figure 1 showed different antibody pattern between seropositive and seronegative survivors. Seropositive survivors were significantly boosted after first dose, while four seronegative survivors remained nonreactive at 14 days after first dose. Antibody titres were higher in seropositive survivor after first dose compared to nonsurvivor and seronegative survivor after second dose. However, anti-RBD titer after first and second dose did not differ significantly in seropositive survivors (Table 2). 
medRxiv preprint doi: https://doi.org/10.1101/2021.05.28.21254613; this version posted May 29, 2021. The copyright holder for this preprint (which was not certified by peer review) is the author/funder, who has granted medRxiv a license to display the preprint in perpetuity.

It is made available under a CC-BY-NC 4.0 International license .

73

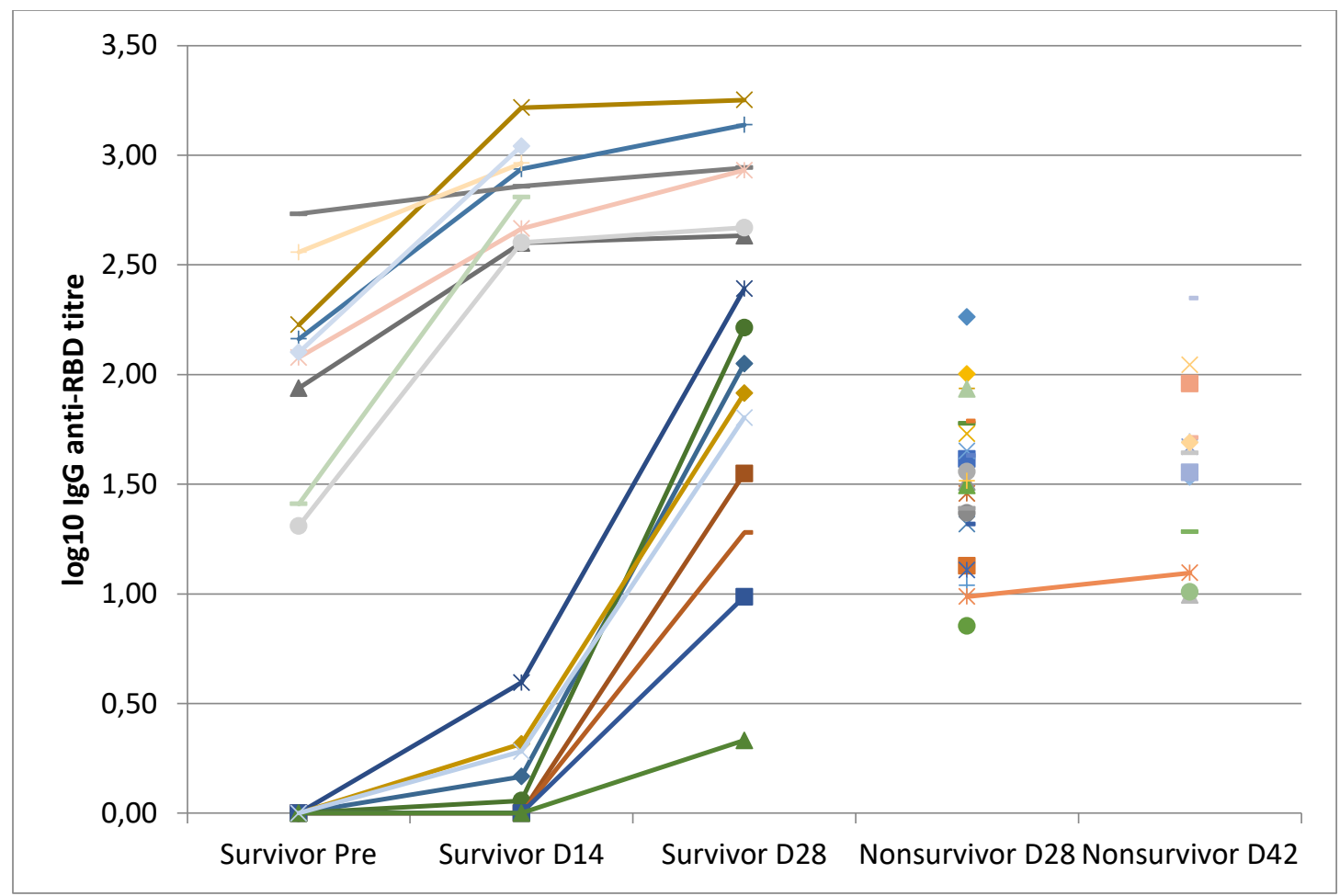

74 Figure 1. Log10 plot of IgG anti-RBD titer 
medRxiv preprint doi: https://doi.org/10.1101/2021.05.28.21254613; this version posted May 29, 2021. The copyright holder for this preprint (which was not certified by peer review) is the author/funder, who has granted medRxiv a license to display the preprint in perpetuity.

It is made available under a CC-BY-NC 4.0 International license . and non-survivors

\begin{tabular}{|c|c|c|}
\hline \multicolumn{1}{|c|}{ Groups } & n & GMT [95\% CI] \\
\hline Non-survivor* & & \\
\hline Day 28 & 24 & $32.7[23.4-45.8]$ \\
\hline Day 42 & 14 & $38.8[23.0-65.2]$ \\
\hline Survivor** & & \\
\hline Seronegative D28 & 9 & $41.0[12.9-130.6]$ \\
\hline Seropositive pre-vaccination & 9 & $114.2[50.0-261.0]$ \\
\hline Seropositive D14 & 9 & $648.6[360.7-1,166.0]$ \\
\hline Seropositive D28 & 6 & $845.5[466.7-1,531.8]$ \\
\hline CoronaVac Phase II trial $^{5}$ & 117 & $27.6[22.7-33.5]$ \\
\hline
\end{tabular}

*One non-survivor was tested at both days 28 and 42 .

78 ** Three seropositive respondents were not tested at day 28.

This preliminary data showed different response pattern between seropositive and seronegative survivors after vaccination with CoronaVac, a whole-inactivated COVID-19 vaccine. We argue that seropositive survivors still need to be vaccinated, at least once. Rise of variants of concern capable of immune escape warrants better immunity response against SARSCoV-2. Previous study on mRNA vaccine showed vaccinated survivor had increased antibody titre and neutralising activity on both Wuhan Hu-1 and B.1.35.1 strains. ${ }^{6}$ Study on an adenovirus-vectored vaccine, ChAdOx1 nCoV-19, also showed high level of neutralising antibodies towards the SARS-CoV-2 wild type and three variants of concern (B.1.1.7, B.1.35.1, and P1) in survivors receiving a single dose of vaccine. ${ }^{4}$ Whether the same can be observed from whole-inactivated vaccine remains to be observed.

Table 2. Geometric Mean Titer of post-vaccination IgG anti-RBD between COVID-19 survivors 
medRxiv preprint doi: https://doi.org/10.1101/2021.05.28.21254613; this version posted May 29, 2021. The copyright holder for this preprint (which was not certified by peer review) is the author/funder, who has granted medRxiv a license to display the preprint in perpetuity.

It is made available under a CC-BY-NC 4.0 International license.

This preliminary study has limitations. We only included small number of respondents,

91

92

93

94

95

96

97

98

99

100

101

102

103

104

105

106

107

108

109

110

111

112

113 most of them are young healthcare workers. This was due to their prioritisation in the first

vaccination phase. However, we plan to include more participant as vaccination eligibility

grows. We also only focused on single antibody, IgG anti-RBD, without neutralisation data.

However, CoronaVac study found high positive correlation between IgG anti-RBD titer with neutralising antibody to live SARS-CoV-2 at 14 days $(0.80,95 \%$ CI $0.75-0.86)$ and 28 days

$\left(0.85,95 \%\right.$ CI 0.82-0.92) after second dose. ${ }^{4}$

Finally, this study showed that seropositive survivor had significant increase on $\operatorname{IgG}$ anti-

RBD titer after first CoronaVac vaccine, but second dose did not significantly increase the titer.

Therefore, antibody testing (preferably using rapid kit) might be incorporated into the screening

process prior to first vaccination dose to enable prioritisation of booster doses for seronegative

individuals. This could potentially ease the vaccine supply constrain. A long-term follow-up

must be conducted to observe difference in antibody response and persistence.

\section{References}

1. Krammer F, Srivastava K, the PARIS team, Simon V. 2021. Robust spike antibody responses and increased reactogenicity in seropositive individuals after a single dose of SARS-CoV-2 mRNA vaccine. medRxiv. DOI: 10.1101/2021.01.29.21250653

2. Saadat, Tehrani ZR, Logue J, et al. 2021. Binding and neutralization antibody titers after a single vaccine dose in health care workers previously infected with SARS-CoV-2. JAMA. Published online March 01, 2021. doi:10.1001/jama.2021.3341

3. Manisty C, Otter AD, Treibel TA et al. 2021. Antibody response to first BNT162b2 dose in previously SARS-CoV-2-infected individuals. Lancet. DOI: 10.1016/S01406736(21)00501-8 
4. Havervall S, Marking U, Greilert-Norin N, et al. 2021. Antibody responses after a single dose of ChAdOx1 nCoV-19 vaccine in healthcare workers previously infected with SARS-CoV-2. medRxiv DOI: 10.1101/2021.05.08.21256866

5. Zhang Y, Zeng G, Pan H, et al. 2021. Safety, tolerability, and immunogenicity of an activated SARS-CoV-2 vaccine in healthy adults aged 18-59 years: a randomized, double-blind, placebo-controlled, phase 1/2 clinical trial. Lanet Infect. Dis. 21(2): P181192. DOI: $10.1016 / \mathrm{S} 1473-3099(20) 30843-4$

6. Stamatatos L, Czartoski J, Wan YH et al. 2021. Antibodies elicited by SARS-CoV-2 infection and boosted by vaccination neutralize an emerging variant and SARS-CoV-1. medRxiv. DOI: 10.1101/2021.02.05.21251182 